\title{
Cicatrizes da memória: fotografias de desaparecidos políticos em acervos de museus*
}

\author{
The scars of memory: the presence in museum archives \\ of photographs of people disappeared for political reasons
}

Cicatrices de la memoria: fotografias de desaparecidos políticos en acervos de museos

\author{
Maria Letícia Mazzucchi Ferreira** \\ Francisca Ferreira Michelon***
}

\begin{abstract}
Resumo: A partir das relações entre imagem e presentificação, o texto analisa os sentidos que os retratos de vítimas das ditaduras apresentam quando são instituídos como acervos museológicos. $\mathrm{Na}$ análise, consideram-se dois aspectos: a condição documental da fotografia e o processo de musealização do documento ao ser exposto. A trama da análise centra-se nos conceitos de memória. Por meio deles, verifica-se um campo de relações em que o apelo ao sentido temporal da indissociabilidade passado-presente e a expressão de uma violência inesquecível somam-se na figuração de certa continuidade. Desse modo, entende-se a fotografia como uma prática discursiva que, no lugar museu (instituição de memória), instala-se como cicatriz: uma marca de sofrimento
\end{abstract}

Palavras-chave: Museus de memória; fotografia; direitos humanos.

Abstract: Utilizing the relationship between image and presentification, the text analyzes the meanings that portraits of victims of dictatorships acquire when they are presented within museum archives. In this analysis two aspects are considered: the documentary qualities of the photograph itself, as well as the process of exhibiting the photograph within a museum. The analysis is conducted by employing concepts of memory that establish a series of relationships in which the evocation of a

* Este trabalho é um resultado do financiamento do Conselho Nacional de Desenvolvimento Científico e Tecnológico (CNPq) e Fundação de Amparo à Pesquisa do Estado do Rio Grande do Sul (FAPERGS).

** Doutora em História PUCRS. Docente do Programa de Pós-Graduação em Memória Social e Patrimônio Cultural da Universidade Federal de Pelotas. <leticiamazzucchi@gmail.com>.

*** Doutora em História PUCRS. Docente do Programa de Pós-Graduação em Memória Social e Patrimônio Cultural da Universidade Federal de Pelotas. <fmichelon.ufpel@gmail.com>. 
temporal understanding of past-present indissociability as well as the expression of unforgettable violence become combined in the portrayal of certain continuity. In this way, a photograph is understood to be a discursive practice within the space of a museum (an institution of memory), and is presented as a mark of suffering - a scar.

Keywords: Museums of memory; photography; human rights.

Resumen: A partir de las relaciones entre imagen y presentificación, el texto analiza los sentidos que los retratos de las víctimas de las dictaduras presentan cuando son instituidos como acervos museológicos. En el análisis se consideran dos aspectos: la condición documental de la fotografía y el proceso de musealización del documento al ser expuesto. El centro del análisis recae en los conceptos de memoria. Por medio de éstos, se verifica un campo de relaciones en que el apelo al sentido temporal de la indisociabilidad del pasado-presente y la expresión de una violencia imborrable se suman en la configuración de cierta continuidad. De este modo, se entiende la fotografía como una práctica discursiva que, en el lugar museo (institución de memoria), se instala como cicatriz: una marca del sufrimiento.

Palabras claves: Museo de memoria; fotografía; derechos humanos.

Ao entrar no Museu da Memória da cidade de Rosário, na Argentina, o visitante depara-se com a obra da artista plástica Graciela Sacco denominada Entre nosotros. Nela, reproduzem-se olhares, extraídos de imagens de desaparecidos, de anônimos, de animais através de uma série de placas acrílicas. O objetivo é buscar o encontro entre os olhos captados pela fotografia e aqueles do visitante: um encontro entre a subjetividade do artista e a do receptor sobre o tema do testemunho e sobre a memória visual que constrói nossas recordações.

Neste artigo, busca-se fazer uma reflexão acerca do olhar que é emanado e lançado pela imagem fotográfica nos chamados Museus de Memória. Analisam-se, em particular, duas exposições realizadas em diferentes museus: a exposição Evidências, no Museu da cidade de Rosário, na Argentina, e a série de painéis com fotos de desaparecidos, no Museu da Memória de Montevidéu, no Uruguai.

A partir das relações entre imagem e presentificação, o texto analisa os sentidos que os retratos de vítimas de processos políticos vinculados à violência de Estado apresentam quando instituídos como acervos museológicos. $\mathrm{Na}$ análise, consideram-se dois aspectos: a condição documental da fotografia e o processo de musealização do documento uma vez exposto. A trama da análise centra-se nos conceitos de memória. Por meio deles, verifica-se um campo de relações no qual tanto o apelo ao sentido temporal da indissociabilidade passado-presente como a expressão de uma violência inesquecível somam-se na figuração de certa 
continuidade. Desse modo, entende-se a fotografia como uma prática discursiva que, no lugar museu (instituição de memória), instala-se como cicatriz: uma marca de sofrimento.

As formas com as quais a sociedade consegue elaborar a recordação de um passado traumático e, ao mesmo tempo, homenagear simbolicamente as vítimas da violência de Estado manifestam-se no espaço social. Fazem-no através da demarcação de uma topografia do terror: da construção de monumentos, da implantação de uma sinalética que marca locais onde ocorreram episódios de violência e de resistência. Existem, ainda, memoriais e museus destinados a construir uma pedagogia da memória voltada não apenas para o passado, mas também para o futuro ${ }^{1}$. Essas ações podem ser definidas como processos de buscas memoriais, que implicam tomar decisões e que incidem na proposição de políticas enfocadas na memória e na preservação de traços e testemunhos de um passado marcado pelo sofrimento coletivo (SCHINDEL, 2009).

Os museus de memória são o eixo da reflexão que apresentamos. Eles compreendem-se como um espaço social, um local de produção de práticas e saberes construídos por um conjunto de agenciamentos técnicos, dispositivos materiais e humanos. Aborda-se a exposição como um ponto de partida (DEBARY; ROUSTAN, 2012) para diversas interpretações e apropriações que podem ser suscitadas no observador-visitante. Essa tipologia museológica é resultante de políticas de memória que se vêm implementando em locais onde houve experiências traumáticas a partir de regimes políticos ditatoriais (e outros) caracterizados por transgressões sistemáticas aos Direitos Humanos.

Este texto é resultante da pesquisa que vimos realizando sobre os museus de memória, os quais advêm do trabalho de busca memorial desenvolvido por diferentes atores sociais e convertido em política de memória. Os museus aos quais se refere esta pesquisa são museus públicos, vinculados aos Estados argentino e uruguaio, instituídos para evidenciar a memória traumática de processos políticos vividos naqueles países nas ultimas quatro décadas.

\footnotetext{
' É possível afirmar que os museus e memoriais cuja origem são processos de violência coletiva, impetrados pelo Estado ou outros agentes sociais, fundamentam-se na construção de um aprendizado sobre o passado com suas marcas traumáticas, como algo que, mais do que ser superado, não pode voltar a ocorrer. Nesse sentido o museu ou memorial busca a intervenção, através, sobretudo, de práticas educativas, na construção de futuros possíveis.
} 
Os últimos períodos ditatoriais na Argentina² (1976-1983) e no Uruguai $^{3}$ (1973-1985) foram marcados por violações sistemáticas dos Direitos Humanos. Durante essa época, havia centros clandestinos de detenção, nos quais se levavam a cabo torturas e assassinatos. No caso argentino, ainda, aconteceram sequestros de filhos de prisioneiros políticos, o que originou as maternidades clandestinas e o consequente desaparecimento de recém-nascidos, cujos destinos, em grande parte, são desconhecidos até hoje.

As marcas deixadas por essas práticas de violência e terror levam a que se pergunte como é possível a transmissão da memória e da patrimonialização de bens materiais que se relacionam com tais processos. As evidências e marcas desse período são muitas, tanto na Argentina quanto no Uruguai. Agregue-se a isso a busca por reparação que as vítimas dos processos de violência de Estado almejam. Para esses cidadãos, a memória e o patrimônio são importantes aliados e testemunhos. Os centros clandestinos de detenção, por exemplo, são muitas vezes reconstruídos por meio de relatos de sobreviventes a partir de memórias sensoriais, como a audição, os odores, as condições ambientais. Portanto, esses registros transformam-se em peças imprescindíveis nos processos judiciais em curso.

No conjunto do que Andreas Huyssen (2007) denomina como cultura global da memória, os diversos suportes nos quais ela pode estar ancorada (como memoriais, espaços públicos, expressões artísticas) desempenham um grande papel. Eles atuam como dispositivos

\footnotetext{
${ }^{2}$ No dia 24 de março de 1976 o governo da Presidente María Estela Martínez de Peron foi destituído através de um golpe de Estado comandado pelas Forças Armadas, sendo imediatamente instalada uma Junta de Comando Militar liderada pelo general Jorge Rafael Videla. Um processo autodenominado de Reorganização Nacional é levado a termo com a dissolução do Parlamento e subsequente instauração de um processo de repressão extremamente violento, atingindo vários setores da sociedade e deixando como uma das heranças mais dolorosas cerca de 30.000 pessoas desaparecidas. Sobre o tema: VEZZETTI, Hugo. Pasado y presente: Guerra,dictadura y sociedad en la Argentina. Buenos aires: Siglo XXI, 2002; ROMERO, Luis Alberto. História contemporânea da Argentina. Rio de Janeiro: Jorge Zahar Ed., 2006; CATELA, Ludmila S. Situação limite e memória: a reconstrução do mundo dos familiares dos desaparecidos da Argentina. São Paulo: Hucitec/Anpocs, 2001.

3 No Uruguai, a ditadura militar foi instaurada em dois momentos distintos. Em 27 de junho de 1973, o presidente eleito Juan Maria Bordaberry, aliado aos militares, assume o poder no país através de um golpe de Estado, destituindo o Parlamento e substituindo-o por um Conselho Militar. Em 1976 os militares assumem definitivamente o poder, afastando assim o presidente eleito. Tal como na Argentina, a ditadura foi marcada por uma repressão violenta deixando um saldo de 6000 prisioneiros políticos, mais de 200 desaparecidos e um país destroçado social e economicamente. Sobre o tema: PADRÓS, Enrique Serra. Como el Uruguay no hay... Terror de Estado e Seguranca Nacional, Uruguay (1968-1985): do Pachecato a Ditadura Civil-Militar. Tese de Doutorado em História/UFRGS, Tomo I. Porto Alegre, 2005. MARCHESI, Aldo. Tupamaros et dictatures. Vingtième Siècle, Revue d'histoire, nº 105, 2010, p. 57-69.
} 
fundamentais para que o trauma vivido na perspectiva do sujeito converta-se em memória coletiva. Tal acepção atribui-se a Maurice Halbwachs (1991), autor que aborda as lembranças individuais como situadas num universo de referências socialmente construídas, pelas quais a recordação é processada. São as tramas sociais nas quais se situa o individuo, assim, que tornam possível a recordação traduzida em linguagem e compartilhada com aqueles que nos cercam.

$\mathrm{Na}$ perspectiva sociológica de Maurice Halbwachs, a lembrança atuaria como ponto de referência frente à variação dos quadros sociais. Isso explicaria por que, em períodos de maior estabilidade social, a memória coletiva teria menos importância, ao contrário de períodos de crise, nos quais ela assumiria grande relevância. Entende-se, nessa perspectiva, que a memória, ao estabelecer uma seleção de quais elementos do passado são necessários no presente, pode ser tratada como fator de coesão social e identidade.

O compartilhamento da memória, sugerido pelo termo memória coletiva, é questionado pelo antropólogo Joel Candau. Ele adverte sobre o cuidado com o qual se deve abordar o conceito a fim de evitar aderir a uma visão essencialista. Para Candau (2011), a memória coletiva definese menos pelo compartilhamento real que pela crença de que o mesmo possa ocorrer. Em outras palavras, a memória, construída através de um discurso que viabiliza a crença no compartilhamento, seria um elemento constitutivo de nossa identidade social. O conceito de metamemória, formulado por Joel Candau, visa a uma compreensão mais ampla da memória coletiva, sendo definido como uma representação que cada indivíduo faz de sua própria memória e tem sobre ela. Nessa linha de compreensão, algumas memórias são mais fáceis de ser compartilhadas (memórias fortes) e outras não (memórias fracas), sendo, para tanto, relevante o papel daquilo que o autor denomina sociotransmissores. Os sociotransmissores são todos aqueles elementos atuantes na construção de discursos memoriais e na sua transmissão, que nos levam a pensar nas políticas de memória e em todos os dispositivos e mecanismos ativados por elas. Os museus seriam, na perspectiva de Candau, poderosos sociotransmissores, uma vez que, através de diferentes recursos com os quais constroem a linguagem expográfica, buscam envolver o observador, levando-o a compartilhar emoções e experiências. Relaciona-se a essa realidade, pois, a ideia formulada por Rancière (2010) de compartilhamento do sensivel.

Os museus de memória seriam, potencialmente, eficazes sociotransmissores para a formação de memória sobre períodos 
traumáticos, fundados em elaborações narrativas que buscam dizer o indizível. Nesse sentido, entender os mecanismos que possibilitam aos museus exercer essa função dentro de um determinado contexto histórico e social leva a que se pergunte: quais formas narrativas são acionadas para representar um passado traumático, uma memória difícil de ser evocada, constituída por sofrimentos individuais e coletivos a que se pode chamar trauma?

É fundamental pensar que o museu, com capacidade midiática expressa na expografia e em outros suportes (DAVALLON, 1992), pode operar como uma das formas sociais de elaborar o trauma. Ele, de fato, converte o trauma em práticas discursivas, compartilhando-o com o universo social representado pelo visitante.

Os museus de memória podem ser classificados como lugares onde a memória ficou cristalizada e materializada no espaço. Como exemplo, há aqueles localizados em cidades que abrigaram atividades associadas à repressão e a atos de violência e transgressão de Direitos Humanos. Existem, também, espaços cuja força memorial provém menos do passado e mais de uma representação através de diferentes mecanismos de linguagens, como a arte, a arquitetura e o tratamento dado às narrativas orais. Dessa forma, vão ao encontro daquilo que Béatrice Fleury e Jacques Walter identificam como mediações memoriais que qualificam e requalificam os lugares $(2011$, p. 21).

Todas as ações levadas a termo pelos museus de memória parecem estar tensionadas entre uma série de alternativas. Dentre elas, aponta-se a possibilidade ou não da representação do sofrimento e do trauma; a escolha pelo realismo ou pela disponibilização de diversos elementos narrativos que levem a reflexões amplas; a busca pelo equilíbrio entre o direito coletivo à memória e aquele individual ao resguardo da experiência vivida.

Nesta modalidade museológica, o visitante é levado, seja pelo realismo do que é exposto, seja pela amostra através da representação, a exercer um papel mais profundo que o de um simples observador. Tornase, pela experiência do fato museal (RUSSIO, 2010), numa espécie de coparticipante da memória traumática e, logo, num responsável por fazer do passado uma lição para o futuro.

Essa experiência do fato museal é possibilitada pela diversidade de instrumentos narrativos museológicos, tais como a imagem fotográfica e, em particular, o retrato de vítimas da violência de Estado. Esta última manifestação, aliás, pode agir como um indutor da sensibilização dos sujeitos às vivências da dor. Por outro lado, tendo em vista os 
atores sociais mais fortemente associados ao trauma, pode colaborar a atenuar a perda ou a presença constante de uma memória controvertida e não pacificada. Nesse sentido, a linguagem artística, presente nos dois museus aqui expostos, sugere que a memória traumática pode se tornar uma obra de arte e, dessa maneira, avançar para uma dimensão universal, ampliando a reflexão para além do representado (VIOLI, 2015).

\section{Os Museus da Memória: Rosário e Montevidéu}

O Museu da Memória da cidade de Rosário foi criado em 1998 por Portaria emitida pelo Conselho Municipal da cidade. Nesse texto, definem-se claramente os objetivos norteadores da instituição e sua localização espacial:

Que a escolha pelo lugar onde será erguido o Museu da Memória deverá significar mais claramente possível a vontade de impor uma condenação definitiva ao terrorismo de Estado, localizandose em prédio que represente um novo triunfo da democracia sobre o terrorismo de Estado e sobre aqueles que ainda hoje persistem em ocultar a verdade. [...] Tornando possível converter um lugar de morte em um espaço para a vida (Ordenanza no 6.506 de la Municipalidad de Rosario).

Em dezembro de 2010, o museu foi transferido para sua atual sede, um prédio projetado por arquitetos italianos em 1928 e conhecido como Casa de los Padres. Em finais dos anos 1940, a casa deixou de ser utilizada como moradia familiar e, desde então, passou a ter diferentes usos. Durante muitos anos, sediou a base burocrática e operacional do Comando do II Corpo do Exército, que ali permaneceu até 1983, momento de transição para a democracia. Posteriormente, o imóvel foi utilizado para fins comerciais, o que perdurou até o ano de 2010.

Visto que era uma base de comando militar durante a última ditadura no país, o local recebia, diariamente, pessoas em busca de informações sobre familiares e amigos desaparecidos. Embora não haja registros de que no interior do prédio tenham ocorrido interrogatórios, torturas ou cárceres, ficaram marcados ali os sentimentos de medo e de apreensão, que tomavam conta dos visitantes em busca de seus entes queridos, sem que nenhuma resposta pudesse ser obtida. 
Terminadas as atividades militares, e após um período de ocupações diversas, o local sediou um projeto de lazer e entretenimento: o bar Rock and Feller's. Descaracterizando o antigo prédio, porém, o bar preencheu com cores e sons um local que, para um grande número de pessoas, havia sido símbolo de sofrimento e de angústia.

A busca pela desapropriação do prédio com fins a alojar o Museu da Memória foi marcada por embates e debates públicos. Tomaramse posições, senão totalmente antagônicas, pelo menos, contraditórias a respeito de se cabia ou não ao Estado assumir, definitivamente, o projeto do museu. Desde suas origens, objetivou-se promover o acesso ao conhecimento e à pesquisa sobre a situação dos Direitos Humanos e sobre a memória social e política na Argentina.

Conforme o diretor da instituição, Rubén Chababo ${ }^{4}$, assumiuse, desde finais de 2011, que o museu não deve existir apenas para sobreviventes ou para antigos prisioneiros políticos. Chababo defende, com convicção, que se devem formular cada vez mais perguntas e elaborar novas e diferentes estratégias de comunicação para que suas mensagens não se esvaziem ao longo do tempo e pelas gerações futuras.

Mais recentemente, através do Decreto Presidencial 379/2015, o museu foi declarado como lugar histórico nacional por indicação da Comissão Nacional de Museus, Monumentos e Lugares Históricos. O Decreto ressalta que "neste edifício, durante os anos da última ditadura cívico-militar, foi planejado o genocídio que se levou a termo em seis províncias argentinas: Santa Fé, Entre Rios, Corrientes, Misiones, Formosa e Chaco" (Decreto 379/2015).

O dilema sobre o que e como representar as memórias dolorosas do ultimo período ditatorial na Argentina perpassa as opções expográficas do museu. A arte, como linguagem e expressão, aparece no museu como uma possibilidade de composição entre a cultura visual e os relatos memoriais. Busca, assim, imprimir no visitante reflexões que derivam menos do impacto emotivo e mais da necessidade de compreensão da mensagem, nem sempre explícita, no objeto museal. Nesse sentido, as obras artísticas que ocupam os dez espaços expográficos do museu remetem, ao mesmo tempo, para elas em si, como inscrições autorais e artísticas e para a memória dos processos de violência

\footnotetext{
${ }^{4}$ Entrevista realizada por Maria Leticia Mazzucchi Ferreira no dia em 12 de junho de 2014, no Museo de La Memoria de Rosario. O arquivo de áudio desta entrevista constitui parte do acervo documental do Projeto "Museus de memória: a (in)comunicabilidade da dor e os limites do dizível”, financiado pelo CNPq e FAPERGS.
} 
que transparece discursivamente em cada uma. As obras de artistas locais estão distribuídas interna e externamente ao prédio e compõem o acervo de longa duração do museu: Memora, de autoria do artista plástico Dante Taparelli, pela qual se pode ler atos de violência de Estado ao longo da história latino-americana; Nos queda la palabra, de autoria da equipe de profissionais do museu, pela qual se escutam relatos de sobreviventes, militantes e familiares de desaparecidos e vítimas da violência na Argentina; Lectores, obra dos artistas Federico Fernández Salaffia e Lucrecia Moras, na qual o livro passa a ser um vetor discursivo da memória e da ausência; Reconstrucciones, uma espécie de cartografia dos centros clandestinos de prisão e tortura na Argentina, com videoinstalação da artista Julieta Hanono; Ronda-la ardiente paciencia, obra de Daniel García, que alude às rondas das Mães da Praça de Maio, com áudio projetado por Hector De Benedictis; Justicia Perseguirás, em que se faz uma vídeo-projeção da trajetória de lutas pela verdade e justiça, elaborada por Pablo Romano; Pilares de la Memoria, com ideia do artista Dante Taparelli e desenho de dez colunas metálicas por Martín Gatto, sobre as quais estão inscritos os nomes de vítimas do terrorismo de Estado; Entre Nosotros, de autoria de Graciela Sacco, instalação feita com espelhos e placas acrílicas nas quais estão impressos olhares de pessoas e de animais, como evocação aos testemunhos; Evidencias, instalação feita pelo artista Norberto Puzzolo a partir de imagens cedidas pelas avós da Praça de Maio, na qual se evoca a constante busca de reconstituição de identidades de crianças que foram retiradas de suas famílias biológicas durante o período da ditadura militar, e cujos destinos, em parte, perderam-se nesse processo de violenta desconstrução da memória, mas vêm sendo recuperados pelas pesquisas genéticas e pela ação sistemática dos órgãos de Direitos Humanos no país. As exposições citadas têm catálogos? Eles devem aparecer como fontes consultadas ao final do texto.

O Centro Cultural e Museu da Memória (MUME), inaugurado em 10 de dezembro de 2007, está localizado na cidade de Montevidéu e é formalmente vinculado ao Departamento de Cultura da Intendência da capital uruguaia. Situado fora do eixo central da cidade, o museu ocupa um prédio que, no passado, foi propriedade do ditador Máximo Santos (1874-1889), um dos representantes do militarismo uruguaio do século XIX.

Conforme material de divulgação do local, o museu destina-se a recuperar a memória do terrorismo de Estado e da resistência à ditadura 
vigente entre os anos 1973 e 1985. Como coordenador desde a fase de projeto da instituição, está o arquiteto Elbio Ferrario: uma das próprias vítimas da violência perpetrada pelo Estado contra a população civil.

No museu, são realizadas atividades artísticas, educativas, culturais e de pesquisa. A exposição de longa duração organiza-se em diferentes eixos temáticos: a instauração da ditadura militar; a resistência popular; as prisões e os centros clandestinos de detenção; o exílio; os desaparecidos; a recuperação democrática e a luta pela verdade e justiça; histórias inconclusas e novos desafios. O tema dos Direitos Humanos e a participação de associações organizadas de familiares de desaparecidos, sobreviventes, ex-prisioneiros e militantes conferem ao museu o caráter de um local voltado, mormente, a esses atores sociais e com imperioso dever cívico de memória.

Tal como no Museu da Memória de Rosário, os arquivos documentais do MUME vêm sendo consultados, principalmente, por pesquisadores e familiares de pessoas que sofreram violência de Estado no período em questão. Por sua vez, o acervo museológico provém, fundamentalmente, de doações feitas por familiares de desaparecidos e por ex-prisioneiros políticos. Os objetos que compõem o museu são de diferentes tipologias: desde documentos diversos, incluindo aqueles produzidos dentro dos cárceres, até registros de entrevistas orais e fotografias. Conforme afirma Ferrario (2008), na perspectiva museológica que rege as atividades no MUME, os objetos são entendidos como portadores de diferentes significados, como versões de múltiplas interpretações do passado, que caracterizam o museu, portanto, como um espaço potencial de conflitos e de reivindicações memoriais.

\section{Evidências e Carteles de los desaparecidos: arte, fotografia e memória}

A obra Evidencias faz parte do catálogo de exposições de longa duração do Museu da Memória de Rosário. Ela foi elaborada pelo artista plástico Norberto Puzzolo em resposta a uma demanda do museu para uma obra que tivesse, como tema organizador, o processo de apropriação e de assassinato de crianças durante a última ditadura militar na Argentina. O espaço de criação foi um pátio interno do edifício, que comporta uma claraboia pela qual a luz é filtrada ao entrar na peça, uma escadaria em mármore com seis degraus e uma fonte localizada no centro do lugar. 


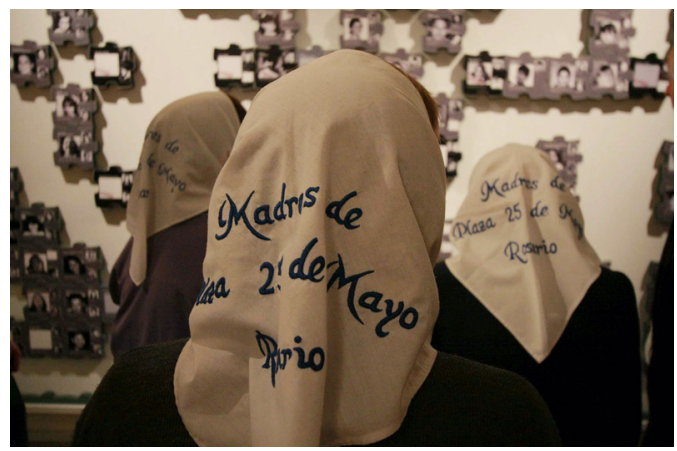

Figura 1

Fonte: Arquivo visual do Museu da Memória de Rosario.

Figura 2

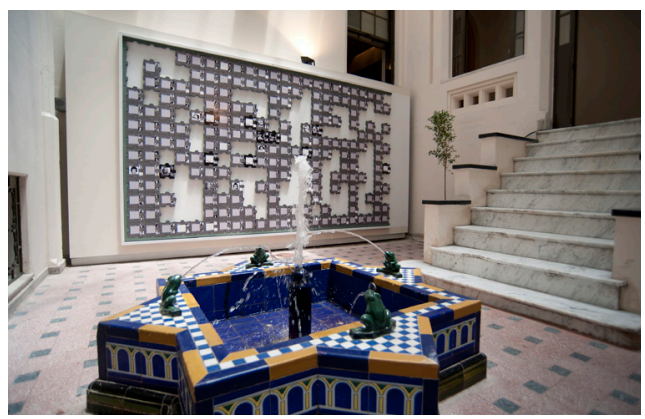

Fonte: Arquivo visual do Museu da Memória de Rosario.

Conforme apresenta Chababo (2012), o projeto utilizou o espaço simulando uma praça pública, na qual se encontram corpos, vozes e olhares. Junto à associação Avós da Praça de Maio foram obtidas as fichas das crianças que ainda são procuradas pela organização e daquelas que já foram resgatadas ou cujo destino já é conhecido. A ideia de um quebra-cabeças, imagem associada à infância e às tramas da memória, tornou-se o suporte para exibir diversas amostras ao visitante. Nele, há em torno de quatrocentas fichas, algumas contendo nomes de pais biológicos vitimados pela ditadura, além de uma série de informações de crianças que, provavelmente, faleceram em partos realizados sob condições precárias nos cárceres. Nas fichas, no espaço destinado às fotografias das crianças, há um vazio extremamente eloquente.

Na parede oposta, há um conjunto de pouco mais de cem fichas, contendo o nome e a fotografia do rosto de uma criança ou de um jovem. Nessa sequência de imagens, as peças se encaixam, indicando que essas crianças (agora adultos) foram já identificadas e reencontraram suas 
famílias biológicas. É uma obra inacabada, porém, com o trabalho do banco de dados genéticos, com as ações das Avós da Praça de Maio e com os órgãos dos Direitos Humanos, aumenta a possibilidade de identificação de crianças desaparecidas. Objetiva-se, pois, reparar, de alguma forma, a perversa prática de fragmentação de identidades e vidas levada a cabo pela última ditadura militar no país.

A exposição conta com uma gravação na qual, simulando a tomada de presença em uma sala de aula, são enunciados os nomes de cada uma das crianças desaparecidas.

No museu da memória de Montevidéu (MUME), algumas peças do acervo, dispostas em um pequeno espaço, chamam a atenção do olhar visitante: são dezenas de fotografias ampliadas e fixadas em hastes de madeira, suspensas por fios invisíveis. Essas peças são identificadas por uma legenda: carteles de los desaparecidos (cartazes dos desaparecidos). São fotografias de desaparecidos durante a última ditadura militar que assolou o país, cedidas ao museu por familiares e amigos e que representam a resistência da memória do ausente frente à ação do tempo e do esquecimento público.

Esses cartazes compõem o acervo de longa duração do museu, sendo, até o ano de 2014, retirados do seu espaço e de sua condição de objeto museológico, sobre o qual incidem todos os processos de conservação preventiva, todo dia 20 do mês de maio. Nesse dia, familiares de desaparecidos utilizam-nos para sua incursão nas ruas da cidade, na manifestação denominada Marcha do silêncio, que reivindica verdade e justiça e frente à qual os rostos estampados nos cartazes são, ao mesmo tempo, memória e denúncia.

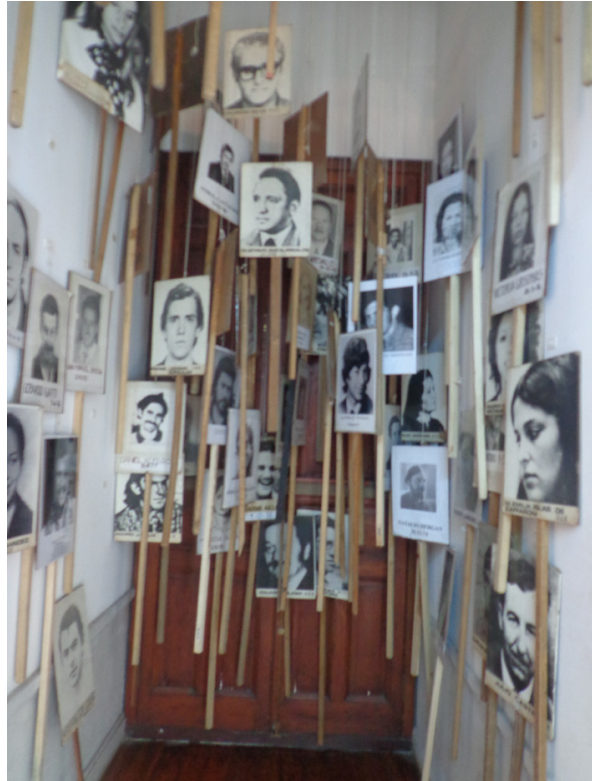

Fonte: Acervo pessoal de Ana Paula Brito. 


\section{Fotografia, ausência e a memória irreparável}

Na prosa poética de Jorge Luis Borges, as figuras bíblicas de Abel e Caim encontram-se após a morte ${ }^{5}$. Passados alguns momentos, o fratricida lembra-se do próprio crime, pedindo perdão ao irmão, que responde não saber do ocorrido. Assim, Caim constata que já foi perdoado, porque "esquecer é perdoar". No conto infantil de C.S. Lewis $O$ sobrinho do mago, os personagens encontram "o bosque entre dois mundos", um lugar mágico onde quanto mais se fica, mais se esquece, até não saber quem se é; onde o tempo para e a eternidade torna-se apenas presente contínuo, morte completa. A pena de damnatio memoriae, infligida pelos romanos antigos a graves traidores do império, por sua vez, implicava o confisco das propriedades do condenado (já morto ou a ser) e a eliminação do seu nome e de sua figura de qualquer suporte que pudesse registrar sua existência. Na literatura, na arte, na história, portanto, o esquecimento é redenção ou tormento e a memória é castigo ou recompensa. Em ambas as situações, os suportes mantêm a lembrança sobre marcas e vestígios, em um lugar de resguardo para o passado.

É sobre vestígios que se está a pensar e que, neste texto, são tidos como equivalentes a marcas: o resultado de uma ação, intencional ou não, sobre um suporte que permanece para além do fato que registra. Esta é uma definição possível de aplicar à fotografia: um suporte para a memória. No entanto, não é bem claro como isso ocorre. Há de se perguntar se esse é um potencial da fotografia, se é uma condição que emerge ou se notifica em determinado evento, se vem a ser em decorrência de um contexto ou se constitui um elemento estruturante da imagem fotográfica. Em caso de que seja esse último, há de se perguntar se poderia ser uma característica geral de qualquer fotografia.

Os elos e os contornos que definem a experiência estética e sensorial que o visitante tem ao se encontrar com as duas exposições desta análise são uma possibilidade de resposta. Primeiro, percebe-se o fato do esquecimento que destitui de materialidade mesmo a vivência mais densa. Ilustra bem a cena imaginada por Borges de Abel e Caim, reencontrando-se no deserto, no vazio, no local onde tudo remonta à serenidade do desimportante e, de igual modo, à figura do bosque entre mundos. Esse lugar, o nada, é uma alegoria da ausência completa, um possível sentido, profundo e integral, do desaparecimento. No entanto,

5 BORGES, Jorge Luis. Lenda. Elogio da Sombra. Obras Completas de Jorge Luis Borges. São Paulo: Globo, 1999. v. 2. 
mesmo sendo o desaparecimento a tragédia, conhecê-lo é a proteção que se tem sobre a maior penalidade: o desvanecimento conceitual, o nome retirado da pedra, os bustos desfeitos. É no sentido da permanência que ingressa a fotografia e, neste caso, o retrato.

De tal gênero fotográfico, fala-se sempre a partir de uma estética da representação que enuncia não somente o modo da imagem, mas também aquilo que Serén (1997, p.10) observou como a gramática técnica, estética e social de um discurso (visual) que se rodeia do simbólico, porque, nele, o sentido mais profundo é irrepresentável. O desaparecimento é de difícil representação, ainda mais na fotografia. A fotografia, como as imagens em geral, é mais eficiente em mostrar que em enunciar; em expressar que em descrever: essa é a sua fraqueza e, na mesma intensidade, a sua força, porque não o fazendo, instaura-se no espectador o estímulo pelo sensível, um apelo para a imaginação. Em um ambiente em que mesmo a imagem se explique (um retrato, enquanto presença referida de um ausente, não demanda outra explicação a não ser referi-lo), o conteúdo do sentimento não se estabelece na lógica de argumentos palpáveis e explicáveis. Neste, a fotografia passa a operar como um vetor que induz o pensamento pelas conexões que estabelece e pela excitação que o sentimento de realidade e de documentação produz na enervação da trama dos estímulos sensoriais (a palavra escrita, a voz, o ruído, a forma, a luz, a sombra).

Assim, todo retrato parece ser um depósito da pessoa que retrata. O retrato de alguém, portanto, dentro dessa lógica das aparências, faz saber que é possível imaginar aquele que ali está a partir de um grau de irrepresentabilidade, mas não nos permite, apenas pela imagem, saber de quem é (o que equivaleria a saber quem é).

Trata-se de um paradoxo que se conhece de muitos modos, a exemplo das quatro fotografias feitas em Auschwitz, de modo inimaginável, por membros do Sonderkommando, e sobre as quais Didi-Huberman (2004) devota sua análise. Essas imagens mostram pessoas sendo encaminhadas às câmaras de gás e foram tiradas, possivelmente, por prisioneiros em situação de perigo extremo, chegando à Resistência polonesa e divulgandose a público apenas após o término da guerra. Da forma e nas condições em que foram feitas, são imagens débeis, que não dimensionam o horror do que acontecia. No presente, são exemplares do modo como pode a imagem fotográfica apresentar e surpreender, uma vez que sua potência não reside no que mostram, mas no fato de terem sido feitas. A dimensão do extermínio não era representável, mesmo que houvesse condições para que alguém fotografasse detalhes das câmaras, dos corpos empilhados, 
das esqueléticas prisioneiras, totalmente despidas e empurradas para a solução final. Nesse caso, o testemunho que a fotografia fornece é raquítico se for considerada a quantidade e a qualidade da informação que consta na imagem. Não obstante, sabendo-se o que foi o Holocausto e a origem dessas fotografias, ocorre o seguinte fenômeno: sem representar e apresentando pouco, desvela-se o portal da imaginação. Assim, as fotografias são enviadas do tempo, certificadoras de fatos e coisas que perderam a sua materialidade, mas que podem, através das imagens, ser imaginadas. O noema de Barthes (1984) ainda aflige; "isto foi”. No entanto, tal condição não diminui o paradoxo inerente à fotografia: a sua mudez não recalca o efeito do ato de apresentação, que também lhe é próprio.

$\mathrm{O}$ que as situações analisadas, Evidências e Carteles de los desaparecidos, utilizam como veia pulsante de uma estrutura de estímulos relacionados, é o retrato fotográfico de vítimas de perseguições políticas, desaparecidas ou reaparecidas. Cada retrato é uma história e todas as histórias conectam-se pela condição que lhes foi impingida e, agora, pela monumentalidade que formam em conjunto. São duas realidades que merecem ser analisadas pelo que as aproxima e pelo que as particulariza. Em ambas, o detonador das significações é a ausência como resultado de perda. É pelo sentido de perda que se aciona a expressão imaginativa e o mergulho nas águas profundas de um sofrimento irreparável. Águas profundas e reprodutivas. Uma vez estabelecido o nexo primordial - a presença da imagem, a ausência do retratado -, os outros sentidos abundam vertiginosos pela contaminação dos recursos (o texto, a voz, o ruído, a forma, a luz, a sombra, como já dito). São infecções propagadas pelas imagens que se acumulam sem libertação possível. A angústia da irreversibilidade traduz-se na impossibilidade da reparação. As crianças e os seus pais não estão ali. Expostos em um suporte de sentido já determinado (as peças de um quebra-cabeça), eles não dizem nada sobre o que apresentam (as pessoas nas imagens) ou dizem pouco (uma criança e um casal adulto: filho e pais). Portanto, não há dramaticidade nesses retratos (alguns retratados até sorriem). A tragédia não se insurge nessas fotos, nem por elas, mas também não se constituiria tal como se constitui se outro suporte ou meio tivesse sido utilizado, em vez do retrato.

O local da exposição Evidências é um átrio sereno, simétrico e ordenado, uma área arquitetonicamente cenográfica pela luz filtrada e difusa que ingressa através da claraboia. O texto é sumário e a narração (a voz da professora chamando cada aluno pelo nome) é prosaica. Isoladamente, esses componentes não sugerem a macabra ocorrência das 
violações às quais se referem no conjunto; assim como a metáfora, o sentido advém da concessão de adjetivos que um elemento faz a outro. A articulação é contínua, portanto, o espectador deve parar para perceber os sentidos; deve olhar, ler, escutar, aproximar-se e afastar-se das paredes que contêm os painéis. Deve movimentar-se num cemitério falsamente idílico de lápides com inscrições e fotos tumulares (ver essa cena é opcional ao visitante), deve enxergar as formas que as peças do quebra-cabeça formam. Se assim o fizer, sua recompensa será o tempo da lembrança, que é tão sua quanto o é da humanidade: a perda a todos pertence.

Os Carteles de los desaparecidos pertencem a outro âmbito expositivo, tão mais surpreendente quanto original. Colocados dentro de um museu, musealizaram-se como acervo (na atualidade, em definitivo), mas, ao longo dos anos, continuaram a servir ao fim para os quais foram feitos. Tiveram, pois, a oportunidade de pertencer a uma dupla circunstância: objeto de manifestação, resistência e memória, quando saiam às ruas; peça museológica, quando se circunscreviam ao espaço do museu. Embora não fossem realidades discordantes, a princípio, as circunstâncias favoreceram um lado. A cada retorno ao museu, intensificou-se o sentido simbólico dos cartazes, que, progressivamente, passaram a significar não o objeto da reivindicação (a localização dos entes desaparecidos), mas o fato integral do desaparecimento, da repressão e da violência do Estado ditatorial. E, ainda, as reproduções que agora voltam às ruas no dia 20 de maio, poupando os originais da inevitável degradação que o uso lhes impingia, intensificam a sua condição de acervo, assegurando-se de valor histórico. Indo às ruas, os cartazes substitutos adensam o processo de significação que resguarda aqueles que lhes deram origem. São apenas retratos. No entanto, na exiguidade de sua existência, sem eles, não se poderia ver os rostos que não existem mais e também, consequentemente, não se poderia ter noção sobre a perda.

Em ambos os casos, esses retratos estão sujeitos a dois vetores que operam o processo de musealização. O primeiro é a singularidade. No retrato evidencia-se a identidade, ainda mais quando o retratado não é ilustre. A identidade do sujeito, decorrência da unicidade que não se subjuga ao desconhecimento, é o vetor de impacto que faz saber que aquela imagem refere um ser real. Portanto, sendo ou não exemplar único, o retrato é, via de regra, o conteúdo da imagem: é único. $\mathrm{O}$ segundo vetor é a representatividade. O objeto museológico representa um período, um saber, uma expressão de cultura. Pelo objeto, há a possibilidade de remontar-se um tempo (de origem e de uso funcional), de supor os modos do existir suplantados ou transformados. Os objetos 
de museus funcionam como pistas, como documentos, como vestígios etc., sugerindo a investigação e a verificação. Os retratos são objetos dóceis no processo de musealização, mas estes retratos em si operam no conjunto. Assim, não se envolve docilidade e sujeição, mas persuasão.

O conjunto, nele mesmo, significa. Quem perde, sofre a dor solitária, mas esse tipo de perda tem um sentido coletivo. Aquele que foi perdido é a história do ser, mas o contexto da perda é a história da nação. Portanto, a narrativa dessas exposições e desses acervos musealizados é sempre narrativa de contexto, ainda que a história individual não se dilua. A fotografia de um desaparecido produz reflexão e pode sensibilizar determinado espectador; as fotos de muitos desaparecidos, colocadas lado a lado, impactam quantos estiverem frente a elas. É uma relação dimensional que participa de um princípio de referência para o espectador: identificar-se com o singular ou imaginar-se no plural. Mais fácil, o segundo.

No conjunto, sem nada representar, a fotografia acusa. A conjunção dessas imagens, seja qual for o suporte que lhes deem, evoca a cena de um cemitério com os esquifes abertos. Não vem a ser esta uma propriedade do retrato, mas um resultado do contexto e que não se inscreve apenas nas aparências, mas no sentido das relações entre as coisas. As coisas são o espaço, a palavra, a finalidade dos museus (que, na sua forma, cumprem a missão de ser museus dos ou para os direitos humanos), a sua representatividade, o seu discurso e o público. Há de se ter em conta que, em um museu, o público é um agente da exposição, que pode, e consegue, ressignificá-la. Retratos de desaparecidos contêm um elemento adicional no sentido da singularidade: a tragédia. Talvez por essa razão suscitem a encenação, ou seja, a justaposição de recursos que, recorrentemente, constituem o fato expositivo: a cenografia, o arranjo espacial, a teatralização e a narrativa metafórica. Assim, são um apelo aos sentimentos dos espectadores. A experiência estética vem precedida pela tragédia intuída, sensação de dor irreparável. O sentimento dos muitos rostos registrados pela fotografia estimula-se pelo desterro e pelo desaparecimento. Esperável que isso aconteça em um museu, porque esses retratos são gemidos da memória, que atravessam os tempos como cicatrizes, que não podem desaparecer enquanto existir o corpo que as carrega.

\section{Considerações finais}

A imagem fotográfica pode ser abordada como o resultado de uma ação intencional: fixar o momento, torná-lo permanente frente à impermanência do curso da vida. Associando a intenção do fotografado, o olhar de quem fotografa e a leitura interpretativa de quem observa, a 
imagem fotográfica é um suporte memorial, uma evidência do passado e, simbolicamente, a presença do ausente.

A fotografia, como peça de acervo pessoal ou coletivo, tem uma visibilidade e expressividade que lhe é concedida pelo contexto no qual se encontra e mobiliza, pela percepção do mundo que podemos ter a partir dela, pelas emoções e pelos sentimentos que se articulam a partir da memória visual. Uma fotografia num cartaz pode ser a grande denúncia da violência e transgressão dos Direitos Humanos, percebida e interpretada a partir das referências da violência dos processos políticos que a memória identifica. Esse reconhecimento, indicador da memória feliz ${ }^{6}$ abordada por Ricoeur (2007), possibilita que um olhar, um retrato fotográfico, uma cena prosaica da vida cotidiana, transformem-se em percepções de um passado doloroso.

A musealização da dor, nessa abordagem, busca fazer, a partir de uma memória intima e individual, outra coletiva na perspectiva do compartilhamento metamemorial. Essa patrimonialização através do ingresso de objetos, de relatos e de outros materiais como acervo museológico, pressupõe um trabalho do luto, um tempo para reinventar o sentido da vida, uma outra maneira de dizer o que está no campo do indizível.

A transmissão, ponto de partida e objeto da ação patrimonial, quando se refere a essa herança da violência e da transgressão dos Direitos $\mathrm{Hu}-$ manos, é a estratégia levada a termo pelas ações museológicas. Por meio dela, permite-se repassar às gerações futuras a capacidade de reconhecer 0 passado não apenas como uma dívida para com aqueles que vivenciaram o sofrimento, mas também como uma pedagogia para a vida presente com as inúmeras violências aos quais estão submetidas nossas sociedades.

\section{Referências}

BARTHES, Roland. A câmara clara. Nota sobre a fotografia. Rio de Janeiro: Nova Fronteira, 1984.

BORGES, Jorge Luis. Lenda. Elogio da Sombra. Obras Completas de Jorge Luis Borges. São Paulo: Globo, 1999. v. 2.

CANDAU, Joel. Memória e Identidade. São Paulo: Contexto, 2011.

CATELA, Ludmila S. Situação limite e memória: a reconstrução do mundo dos familiares dos desaparecidos da Argentina. São Paulo: Hucitec/Anpocs, 2001.

CHABABO, Rubén. Norberto Púzzolo: antes y después del naufrágio-Catálogo de la muestra Evidencias. Rosario: Museo de la Memoria, 2012.

\footnotetext{
${ }^{6}$ Conforme Paul Ricoeur, memória feliz seria "o reconhecimento de uma coisa rememorada, percebido como uma vitória sobre o esquecimento", logo "é preciso nomear o esquecimento para falar em reconhecimento". Assim, "encontrar é reencontrar, e reencontrar é reconhecer, e reconhecer é aprovar, logo, julgar que a coisa reencontrada é exatamente a mesma que a coisa buscada e, portanto, posteriormente considerada como esquecida (2007, p. 110).
} 
DAVALLON Jean. Le musée est-il vraiment un média? Publics et Musées. № 2. Presses Universitaires de Lyon, 1992. p. 99-123.

DEBARY, Octave; ROUSTAN, Mélanie. Voyage au musée du Quai Branly. Anthropologie de la visite du plateau des collections. Paris: La Documentation Française, 2012.

DIDI-HUBERMAN, George. Imágenes pese a todo: Memoria Visual del Holocausto. Barcelona: Paidós Ibérica, 2004.

FERRARIO, Elbio. Da luta pela liberdade, democracia e justia social. In: BEZERRA, Rafael Zamorano; CHAGAS, Mário; BENCHETRIT, Sarah. (Org.). A democratização da memória: a função social dos museus ibero-americanos. Rio de Janeiro: Museu Histórico Nacional, 2008. v. 1, p. 53-70.

FLEURY, Béatrice; WALTER, Jacques. Memorias de la piedra-Ensayos en torno a lugares de detención y massacre. Buenos Aires: Ejercitar la memoria Editores, 2011.

HALBWACHS, Maurice. A memória coletiva. São Paulo: Vértice, 1991.

HUYSSEN, Andreas. En busca del futuro perdido. Cultura y memoria en tiempos de globalización. Buenos Aires: Fondo de Cultura Economia, 2007.

LEWIS, C. S. As crônicas de Nárnia. O sobrinho do mago. São Paulo: Martins Fontes, 2002. v. 1.

MARCHESI, Aldo. Tupamaros et dictatures. Vingtième Siècle - Revue d'histoire, n. 105, p. 57-69, 2010.

PADRÓS, Enrique Serra. Como el Uruguay no hay... Terror de Estado e Seguranca Nacional, Uruguay (1968-1985): do Pachecato a Ditadura Civil-Militar. Tese (Doutorado em História) - Universidade Federal do Rio Grande do Sul, Porto Alegre, 2005. Tomo I. RANCIÈRE, Jacques. Estética e Politica. A Partilha do Sensível. Porto: Dafne, 2010. RICOEUR, Paul. A memória, a história e o esquecimento. Campinas: Ed. Unicamp, 2007. ROMERO, Luis Alberto. História contemporânea da Argentina. Rio de Janeiro: Jorge Zahar Ed., 2006.

RUSSIO, W. A interdisciplinaridade em Museologia (1981). In: BRUNO, M. C. O. (Org.). Waldisa Rússio Camargo Guarnieri: textos e contextos de uma trajetória profissional. São Paulo: Pinacoteca do Estado; Secretaria de Estado da Cultura; Comite Brasileiro do Conselho Internacional de Museus, 2010. v. 1, p. 123-126.

SCHINDEL, Estela. Inscribir el pasado en el presente: memoria y espacio urbano. Políticas culturales, México, n. 31, enero 2009. Disponível em: $<$ http://www.scielo. org.mx/scielo.php?script=sci_arttext\&pid=S0188-77422009000100005\&lng=es\& nrm $=$ iso $>$. Acesso em: 10 maio 2015.

SERÉN, Maria do Carmo (Introd.). Murmúrios do tempo. 2. ed. Porto: CPF, 2002.

VEZZETTI, Hugo. Pasado y presente: Guerra, dictadura y sociedad en la Argentina. Buenos Aires: Siglo XXI, 2002

VIOLI, Patrizia. Quand l'art rencontre la mémoire. Le musée pour la Mémoire d'Ustica par Christian Boltanski. Actes Sémiotiques, n. 118, 2015. Disponível em: <http:// epublications.unilim.fr/revues/as/5370>. Acesso em: 10 maio 2015.

\section{Fontes}

- Decreto 379/2015 de 5/3/2015 de la Presidencia de La Nación.

- Museo de la Memoria. Disponível em: <http://www.museodelamemoria.gob.ar/page/ institucional/>.

- Ordenanza nº 6.506 de 26/02/1998 da Municipalidade de Rosario. 